\title{
UDC 504.453:550.46
}

\section{MODERN ECONOMIC ACTIVITY AND ITS IMPACT ON THE STATE OF THE RIVER-BASIN SYSTEM OF THE STRYI RIVER СУЧАСНА ГОСПОДАРСЬКА ДІЯЛЬНІСТЬ ТА ЇЇ ВПЛИВ НА СТАН РІЧКОВО- БАСЕЙНОВОЇ СИСТЕМИ РІЧКИ СТРИЙ}

Hnativ I.R. / Гнатів I.P.

postgraduate student / acnipaнm ORCID: 0000-0002-2987-1673

Lviv National Agrarian University, Lviv region, Dublyany, Volodymyra Velykoho str., 1, 30831 Львівський начіональний аграрний університет, Львівська обл., м. Дубляни, вул. Володимира Великого, 1, 30831

\begin{abstract}
Pollutants enter the reservoirs not only with concentrated discharges of industrial and agricultural enterprises or municipal wastewater treatment plants, but a significant part of their receipt is due to the flushing of pollutants from catchment areas. In the Lviv region there are mining areas of mineral deposits, which leads to extremely high anthropogenic transformation of geosystems. Significant problems in the protection of land resources in the catchment area of the Stryi River are the reduction of soil nutrients and their water erosion, as well as insufficient reclamation of disturbed lands. The peculiarity of Carpathian farming is that it passes on the slopes of a significant slope.

The main disadvantages of modern forestry, which activate dangerous exogenous processes in the basins of mountain rivers, in addition to continuous deforestation are the use of the method of skidding wood using heavy machinery. The application of this technology causes the destruction of forest ecosystems, the transformation of the morphology of the slope, the intensification of erosion and landslides.
\end{abstract}

Keywords: pollution of water bodies, anthropogenic impact, economic activity.

\section{Introduction.}

The river network of Lviv region was the basis for the emergence of the first agricultural communities in Eastern Europe. Today it is an area belonging to the region with a high degree of economic development, where the main economic activities are agriculture, animal husbandry, mining, underground, open and downhole, development of deposits of building materials, forestry, water consumption, industrial processing of raw materials, transport, construction, recreation, etc. [1]. There is a continuous exchange of matter and energy between the abiotic and biotic components of river basin systems. The main channels of such communication are water flows, so the problem of optimizing the system of integrated control and monitoring of the state of surface waters and the level of their pollution is especially important on the way to sustainable development of society.

\section{The main text}

Physical and geographical conditions and natural resources of the Stryi river basin determine its basic directions of economic development, namely agrarianforestry and industrial-transport. Being attractive for tourists and ecologically clean, the pool has significant recreational resources. Favorable geographical location, developed network of transport routes, proximity of borders with EU countries provide advantages for improving the economic and socio-cultural development of the territory. The Stryi-Chop railway, the Kyiv-Chop highway pass through the 
territory of the basin, and the "Druzhba" main oil pipeline, which supplies oil to Europe, and the "Mir" high-voltage transmission line pass from the northeast to the southwest [2].

In general, Ukraine is one of the few countries in the world where most types of minerals have been discovered and developed to varying degrees. The results of exploration work in recent years show that the subsoil of the state is also rich in such types of minerals, which in the past were classified as substandard and had no industrial significance. These include non-ferrous (lead, zinc, copper), rare and rare earth metals, deep hydrocarbon deposits, etc. available in Lviv region. Most of them require geological study for possible industrial development in the near future. In the region there are mining areas of mineral deposits, which leads to extremely high anthropogenic transformation of geosystems (fig. 1) [1].

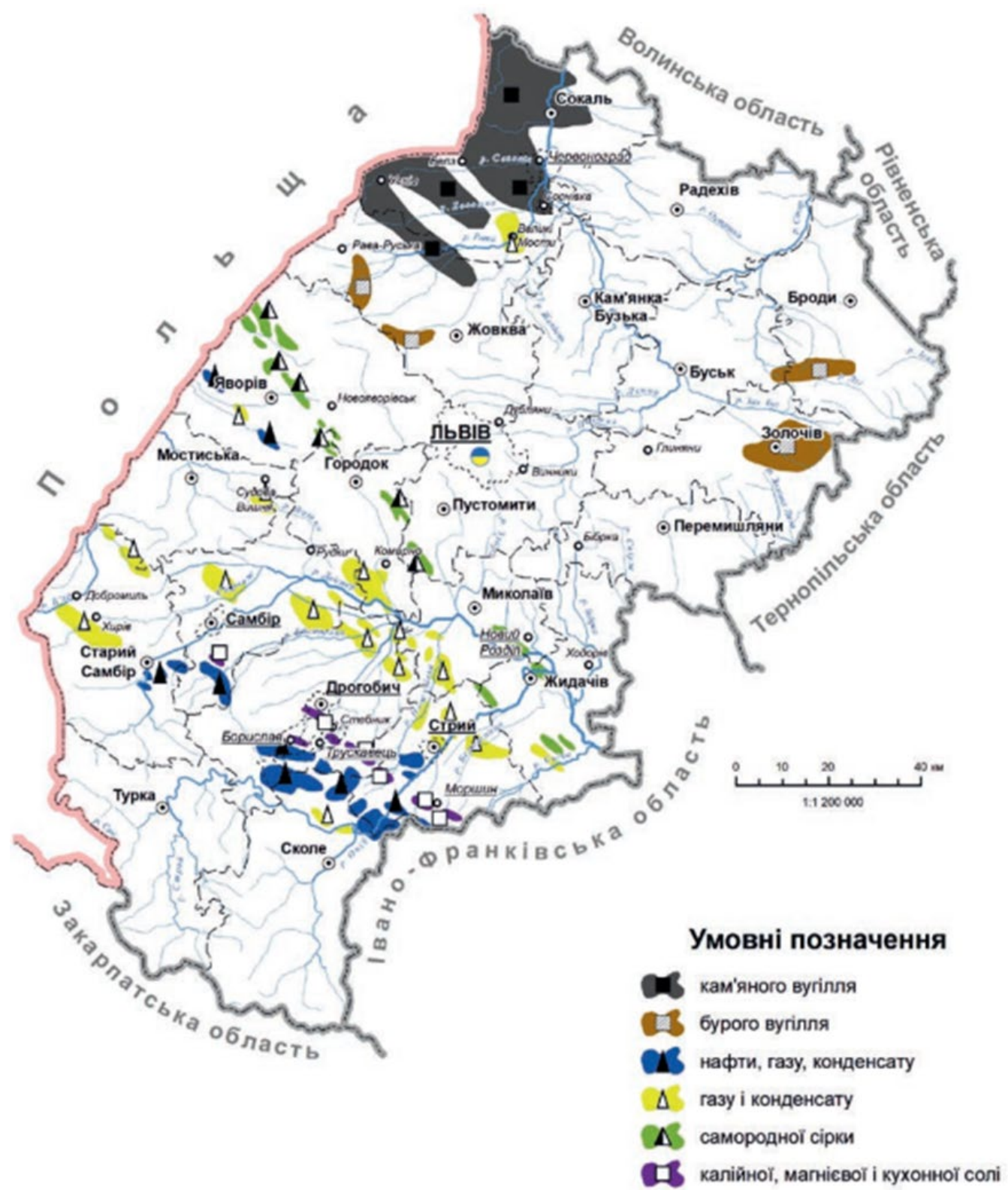

Fig. 1. The main mineral deposits of Lviv region

In the cities of Stryi, Zhydachiv, Skole and Turka, as well as in the territories of some other united territorial communities (UTC) there are enterprises of various 
forms of ownership of machine-building, electrical, logging, transport and service, woodworking, pulp and paper and other areas. Stynavske, Pivdennostynavske, Tanyavske, Skhidnytske, Uritske and Zavodivske oil fields are exploited and hydrocarbons are searched within other licensed areas [3].

Most gas fields are developed in the Syansky and Dniester Pre-Carpathians, as a result of which the Drohobych and Stryi foothills experience a significant mining load. In the Beskids lowlands, all oil and gas fields produce gas together with oil, which increases the intensity of mining impact on landscape systems. Gas fields of Lviv region belong to the system of NJSC Naftogaz of Ukraine. The network of gas pipelines is significantly extensive and includes gas compressors and dozens of gas distribution stations. Old gas fields of Precarpathia are used as underground gas storage facilities to store free gas reserves, which are needed for domestic consumption or export to Europe. Today there are four gas storage facilities in the region [1].

Along the river Stryi, in the area from the village Rozgirche to the village Duliby, the aquifer of the Stryi groundwater deposit with reserves of 270 thousand $\mathrm{m}^{3}$ / day was formed. The field is operated by three coastal water intakes: Zhulynsky, Bratkivsky and Lyubynetsky. Water intake wells are located along the river. Lyubynetky water intake provides water to the cities of Drohobych, Truskavets, Stebnyk, Boryslav, Zhulynsky - Lviv, and Bratkivsky - Stryi and Morshyn [3].

Significant problems in the protection of land resources in the study area are to reduce the content of soil nutrients and their water erosion, as well as insufficient reclamation of disturbed lands. The peculiarity of Carpathian farming is that it passes on the slopes of a significant slope. The studies are executed in the mountainCarpathian experimental station show that only for the autumn-spring period from the optic field is washed to $200 \mathrm{~m}^{3}$ of soil with 1 hectares [4].

Agricultural load on the basin system causes changes in land use model, affects the redistribution of the structure of components and its geochemistry. Prolonged and intensive land use causes changes in the development of ecological and geomorphological processes, morphology of the basin system and its environmental state. The Indicators of the degree of soil erosion and the area of eroded soils are changing, the physical and chemical properties of soils and the morphology of the slopes of river basins are deteriorating. There is a degradation of small watercourses until their complete disappearance, deterioration of water quality in the channels of permanent watercourses as a result of physical and chemical denudation of the basin system. All this negatively affects both the functioning of the basin system and the quality of natural resources, the life of man and its health [5].

Since the early 90 's, as a result of agrarian reform, two categories of agricultural enterprises were formed by private agricultural fixes on the basis of former collective farms and individual-private farms, mostly small deposits. This led to changes in the structure of the use of arable land for agricultural crops, their yields, introduction of organic and mineral fertilizers, mechanical cultivation of lands and significantly influenced the hydroecological and geoecological situation.

Adding mineral and organic fertilizers significantly affect the state of soil and groundwater as a result and in surface water. With products of soil cover in the river, 
more than $30 \%$ of the components of the fertilizers are received [6].

Significant agribusiness of the territory is important to influence the development of forest industry. Mass deforestation in our region began in the XVIII century, and during the XIX century the vast majority of them were cut down in accessible places [7]. Deforestation was carried out on huge areas that stretched from river valleys to the upper limit of the forest. This led to the intensification of harmful geomorphological processes, such as planar and linear erosion of mountain soils, mudslides, catastrophic floods and winds [5, 7]. Further practice of artificial creation of spruce monocultures in the mountains and oak forests in the foothills caused massive damage to stands by root rot, entomo pests, etc. This led to a deterioration of biotic stability of forest ecosystems.

Continuous deforestation has a very negative impact on the flow of mountain streams, so if possible, it is necessary to use gradual and selective deforestation. With gradual felling, the change in water runoff is twice, and after selective - 10 times less than with continuous. Under the influence of continuous deforestation, soil erosion increases rapidly and as a result, the solid runoff of streams increases 10 times [8].

The main disadvantages of conducting modern forestry, which activate the dangerous exogenous processes in the basins of mountain rivers, except for the continuous cutting of the forest, consider the use of a wood shelving using heavy machinery. The use of this technology leads to the destruction of forest ecosystems, reforming the slope morphology, activation of erosion and landslide processes. The tracks used to ski the wood contribute to the emergence and subsequent ascent of the mudflow. Clogging of the slopes with wood residues of different sizes causes the concentration of runoff on the surface of the slope and getting into the channel of the mountain stream unused residues of logging. They cause blockage of mountain riverbeds, change the direction of flow during downpours and floods, concentrate it along dirt roads and cause deterioration of water quality [9].

Spatial analysis of placement of settlements within the basin systems of Prykarpattya indicates the predominance of the linear valley type of resettlement in the mountain and plain parts of the basin and an increase in the village load. This affects the landscapes of the river valleys, causes a change in the morphology of channels, the deterioration of the geoecological situation in the basin systems in general. Particular damage causes deepening and collection of building materials from rivers, location of residential buildings, spontaneous landfills and other potential sources of pollution in coastal protective bands of the river [5].

\section{Conclusion and findings.}

Investigation of the conditions and processes of formation of chemical composition and water quality is an urgent problem to take into account the influence of economic activity on the river basin system of Stryi. The main sources of pollution of river water are rainstorms from the territory of the city and industrial areas that are not cleared, washed out of the catchment areas of fertilizers and pesticides entered into the soil, as well as the disadvantages of modern forestry, which activate the dangerous exogenous processes in the basins of mountain rivers.

Significant volumes of pollution are created by landfills of household and industrial waste in the Stryi riverbed, as well as unauthorized quarrying, which 
worsens the hydrological regime and the process of natural water purification.

\section{References:}

1. Lviv region: Natural conditions and resources: monograph / General editing of Dr. Gegr. Sciences, prof. M. M. Nazaruk. Lviv, Old Lion Publishing, 2018. 592 p.

2. Zastavnyy F.D. Geography of Ukraine / F. D. Zastavnyy - Lviv: World, 1994. T.1. $472 \mathrm{p}$.

3. Karabin V.V. Estimation of natural and man-made risks of pollution by phenols of drinking water of the Precarpathian (on the example of Stryi water intake) / V.V. Karabin, Yu. Z. Kozak, V.V. Kolodiy // Search and ecological geochemistry. 2006. No. 5. P. 35-41.

4. Environmental problems of agriculture Carpathians / F. Topolnyy, O. Gelver, S. Mospan, etc. // Labors NTSh: Ecological collection. T. XI: Environmental problems of the Carpathian region. Lviv, 2003. P. 351-360.

5. Pylypovich O.V. Geoecology of the river basin system of the upper Dniester: Monograph / O. Pylypovich, I. P. Kovalchuk; According to the scientific edition of Professor I.P. Kovalchuk. Lviv-Kiev: LNU named after Ivan Franko, 2017. 284 p.

6. Kovalchuk I.P. Regional ecological and geomorphological analysis / I.П. Kovalchuk. Lviv: Institute of Ukrainian Studies, 1997. 440 p.

7. Krynitsky G. The state of forests of the Ukrainian Carpathians, environmental problems and prospects / G. Krynitsky, P. Tretyak // Labor NTSH: Ecological collection. T. XI: Environmental problems of the Carpathian region. Lviv, 2003. P. 54-65.

8. Byblyuk N.I. Dangerous natural phenomena in the Carpathians: causes of occurrence and ways to minimize them /N.I. Byblyuk, I.P. Kovalchuk, O.S. Machuga // Scientific works of the Lianth Academy of Sciences of Ukraine: a collection of scientific works. Lviv: RVV of NLTU of Ukraine. 2008. V. 6. P. 105-119.

9. Snitynskyi V.V. Influence of extensive forestry activity in landslid and erosion phenomena in the Carpathian region / V.V. Snitynskyi, O.M. Yakhno, P.R. Khirivskyi, I.R. Hnativ, R.M. Hnativ // "Forest Engineering: Technology, Technology and Environment": Collection of Theses International. science. Conf., (NLTU of Ukraine, Lviv, Ukraine, May 28-30, 2020). P. 50-51.

Анотація. Забруднюючі речовини потрапляють у водойми не лише із зосередженими скидами промислових і сільськогосподарських підприємств чи очисних споруд міських стоків, але значна частина їх надходження обумовлена змивом полютантів з водозбірних територій.

На Львівщині діють гірничовидобувні території родовищ корисних копалин, щзо призводить до надзвичайно високої антропогенної трансформації геосистем. Значними проблемами з охорони земельних ресурсів в районі дослідження $\epsilon$ зменшення вмісту поживних речовин трунтів і їх водна ерозія, а також недостатня рекультивачія порушених земель. Особливістю карпатського рільництва є те, щуо воно проходить на схилах значного похилу.

Основними недоліками ведення сучасного лісового господарства, які активізують небезпечні екзогенні процеси в басейнах гірських річок, окрім суцільних вирубок лісу вважають використання способу трелювання деревини за допомогою важкої техніки. Застосування иієї технології спричиняє руйнування лісових екосистем, переформування 
морфології схилу, активізацію ерозійних та зсувних процесів.

Встановлено, щзо основними джерелами забруднення річкової води є дощові стоки з території міста та промислових площ, які не очищаються, змив з водозбірних площ внесених в трунт добрив та отрутохімікатів, а також недостатня очистка стоків на очисних спорудах.

Ключові слова: забруднення водних об'єктів, антропогенний вплив, господарська діяльність.

Стаття відправлена: 22.05.2021 p.

(C) Гнатів I.P. 